\title{
Jules Bernard Luys: from a description of the subthalamic nucleus to hypnotism
}

\author{
Jules Bernard Luys: da descrição do núcleo subtalâmico ao hipnotismo \\ Alex Tiburtino MEIRA', Anieli Fagiani PRODÓSSIMO², Gabriel Sampaio FROEHNER², Gustavo Leite FRANKLIN², \\ Murilo Sousa DE MENESES ${ }^{3}$, Renato Puppi MUNHOZ4, Hélio Afonso Ghizoni TEIVE²
}

\begin{abstract}
The authors review the role of Jules Bernard Luys in the discovery of the subthalamic nucleus (STN) over 150 years ago. The relationships between the STN and movement disorders, particularly hemiballismus and Parkinson's disease, are well known. The academic life of Jules Bernard Luys can be divided into two periods: a brilliant start as a neuroanatomist, culminating in the discovery of the STN, followed by a second period marked by a shift in his academic activity and an increased interest in topics such as hysteria, hypnotism and, eventually, esotericism.
\end{abstract}

Keywords: Subthalamic nucleus; Basal Ganglia Diseases; Movement Disorders; Dyskinesias.

\section{RESUMO}

Os autores revisam o papel de Jules Bernard Luys na descoberta do núcleo subtalâmico (NST) há mais de 150 anos. As relações da NST com distúrbios do movimento, em particular o hemibalismo e a doença de Parkinson, são bem conhecidas. A vida acadêmica de Jules Bernard Luys pode ser dividida em duas fases: a primeira, um brilhante começo de sua carreira como neuroanatomista, culminando na descoberta do NST, seguido por um segundo período marcado por uma mudança em sua atividade acadêmica, e maior interesse em tópicos como histeria, hipnotismo e finalmente esoterismo.

Palavras-chave: Núcleo Subtalâmico; Doenças dos Gânglios da Base; Transtornos dos Movimentos; Discinesias.

\section{INTRODUCTION}

The second half of the $19^{\text {th }}$ century saw the rise to prominence of Jean-Martin Charcot (1825-1893) arguably as the most important and best-known professor of neurology in the world at the time. Charcot established a school of neurology at the La Salpêtrière Hospital in Paris, France, which has become known as the "Mecca of neurology" due to its reputation ${ }^{1}$. The school attracted physicians and young neuroscientists such as Pierre Marie, Joseph Babinski, Gilles de la Tourette, and Jules Bernard Luys ${ }^{1,2,3}$. Luys consists in the subject of this historical note, which reviews his life and contribution to the field of neurology, particularly his studies of the subthalamic nucleus (STN) as well as his great interest in hysteria, hypnotism, and esotericism in the final period of his life.

\section{Jules Bernard Luys - a short biography}

Jules Bernard Luys (1828-1897), a Parisian neurologist, started his anatomical studies as an intern under the supervision of Charles Robin and was awarded a $\mathrm{PhD}$ in medicine in 1857 (Figure 1) ) $^{1,2,4,4,5,6}$. He became the chef de service at the La Salpêtrière Hospital in 1862, when Jean-Martin Charcot had just become director of the clinic for diseases of the

\footnotetext{
1 Univerisdade Federal da Paraíba, Departamento de Medicina Interna, João Pessoa PB, Brazil.

${ }^{2}$ Universidade Federal do Paraná, Hospital de Clínicas, Departamento de Medicina Interna, Serviço de Neurologia, Setor de Distúrbios do Movimento, Curitiba PR, Brazil.

${ }^{3}$ Hospital Ecoville, Instituto de Neurologia de Curitiba, Curitiba PR, Brazil.

«University of Toronto, Toronto Western Hospital, Movement Disorders Centre, Toronto ON, Canada.

Alex Tiburtino MEIRA' (iD https://orcid.org/0000-0002-6685-7491; Anieli Fagiani PRODÓSSIMO² (iD) https://orcid.org/0000-0001-5629-8879; Gabriel Sampaio FROEHNER² (ID) https://orcid.org/0000-0002-7506-3386; Gustavo Leite FRANKLIN² (iD https://orcid.org/0000-0002-0207-3671; Murilo Sousa DE MENESES ${ }^{3}$ (iD https://orcid.org/0000-0002-4514-7079; Renato Puppi MUNH0Z4 (iD https://orcid.org/0000-0002-4783-4067; Hélio Afonso Ghizoni TEIVE² (iD http://orcid.org/0000-0003-2305-1073

Correspondence: Alex Tiburtino Meira; E-mail: alex.m.meira@gmail.com

Conflict of interest: There is no conflict of interest to declare.

Author's contribution: ATM, AFP, GSF, GLF, MSM, RPM, HAGT: conceptualization, investigation, supervision, validation, writing original draft, writing review, editing. ATM, MSM: figure acquisition.

Received on May 1, 2020; Received in its final form on June 9, 2020; Accepted on July 6, 2020.
} 


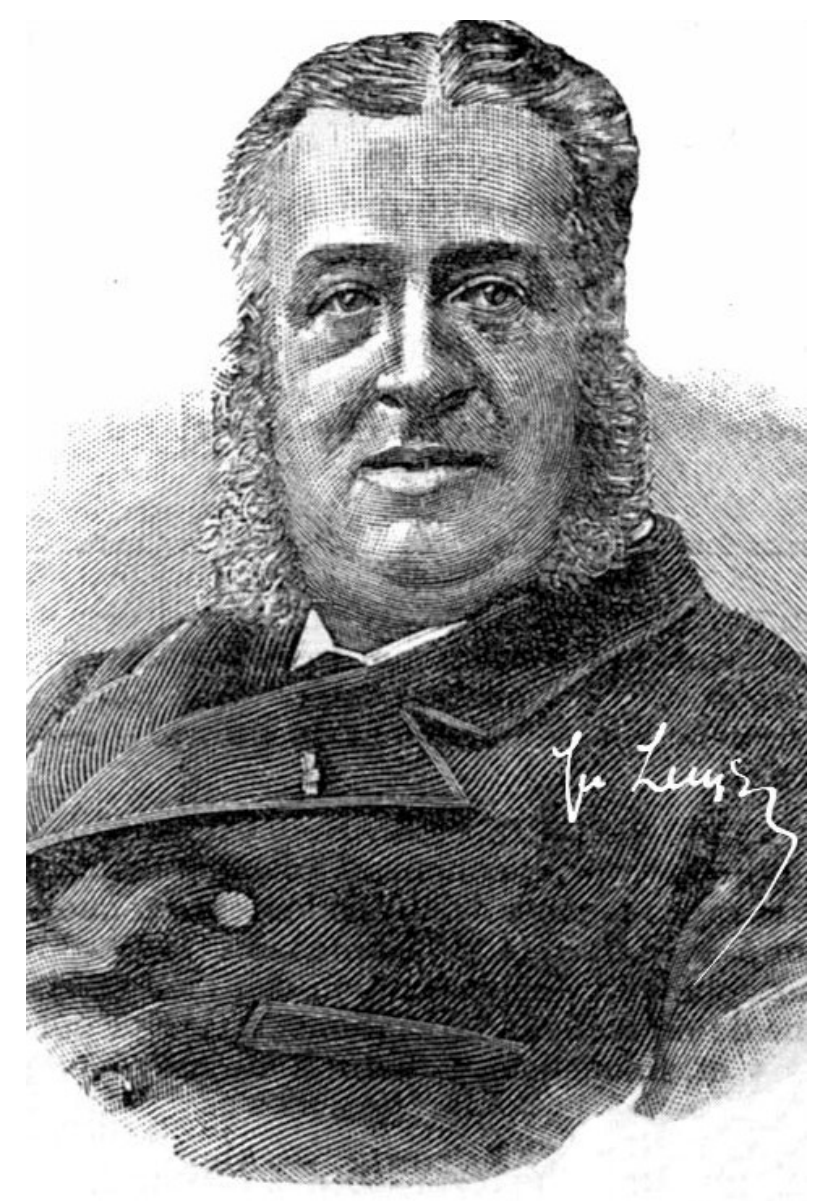

Source: reproduced with permission from reference [6].

Figure 1. Portrait of Jules Bernard Luys (1828-1897).

nervous system ${ }^{2,5,6}$. Luys also worked at the Charité Hospital and became director of the Maison de Santé Esquirol and mental asylum at Ivry-sur-Seine, France. He was co-founder and editor of L'Encéphale (Figure 2), the first “impartial, practical and skeptical" journal on nervous diseases in France, which was published between 1881 and 1889 and republished under the same title in $1906^{2,3,5,6}$. Luys's published works include "Recherches sur le système cérébro-spinal, sa structure, ses fonctions et ses maladies" (1865), a 660-page treatise accompanied by an 80-page atlas containing 40 plates, each with approximately 15 lithographs ${ }^{2,5}$. The book covered the anatomy, pathology, and physiology of the brain and spinal cord. Then, in 1873, there was the publication of two volumes (a textbook and atlas) containing photographs by his son, Georges Luys, with 70 prints reflecting what Jules Bernard Luys had previously tried to show in his lithographs. The motivation behind his pioneering work with photography arose from criticism of the potential subjectivity, and hence inaccuracy, of lithography ${ }^{2,7}$. In addition to his memorable contributions to the field of neuroanatomy, Luys extensively wrote on neuropsychiatry (insanity, hysteria, and hypnosis) $)^{2,8}$. In 1877 he became a member of l'Académie de médecine and was awarded the Légion d'honneur ${ }^{2,49}$.

\section{L'ENCÉPHALE}

\section{JOURN:AL}

DES

\section{MALADIES MENTALES ET NERVEUSES}

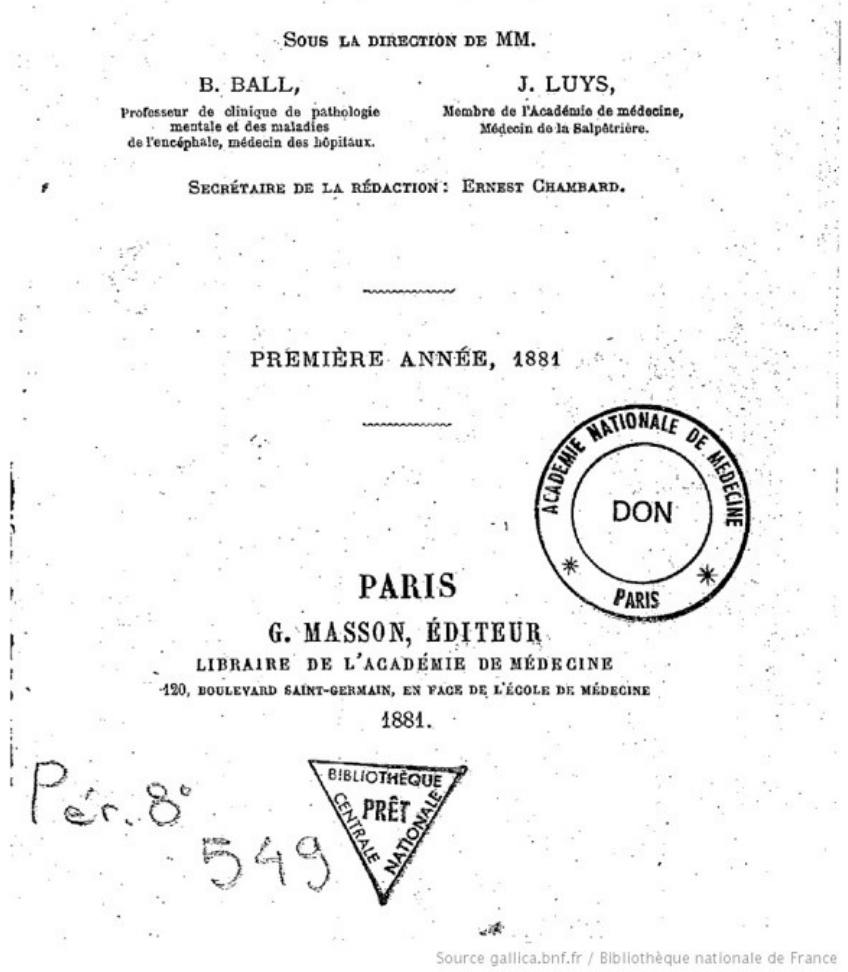

Figure 2. The L'Encéphale journal. First edition, 1881.

Published under the editorship of B. Ball and J. B. Luys ${ }^{24}$.

\section{Luys's masterpiece: a description of the subthalamic nucleus}

Luys made many decisive contributions to neuroanatomy, including various publications and the identification of anatomical structures. Two structures in the forebrain identified by him are still associated with his name: the central medial thalamic nucleus and the STN, or corpus Luysii ${ }^{2,3,5,6}$. The STN was first erroneously described by Luys as the "bandelette accessoire de l'olive supérieure" because of its spatial relationship to the red nucleus, which he called the "olive supérieure",5,5,10,11. Several years later, in 1877, the psychiatrist Auguste-Henri Forel coined the eponym "corpus Luysii" in honor of Luys ${ }^{23,10,11}$. A biconvex structure, the STN is composed of projection neurons located in the diencephalon and is surrounded by dense bundles of myelinated fibers (Figure 3). It is anteriorly and laterally limited by the internal capsule, which laterally separates it from the 


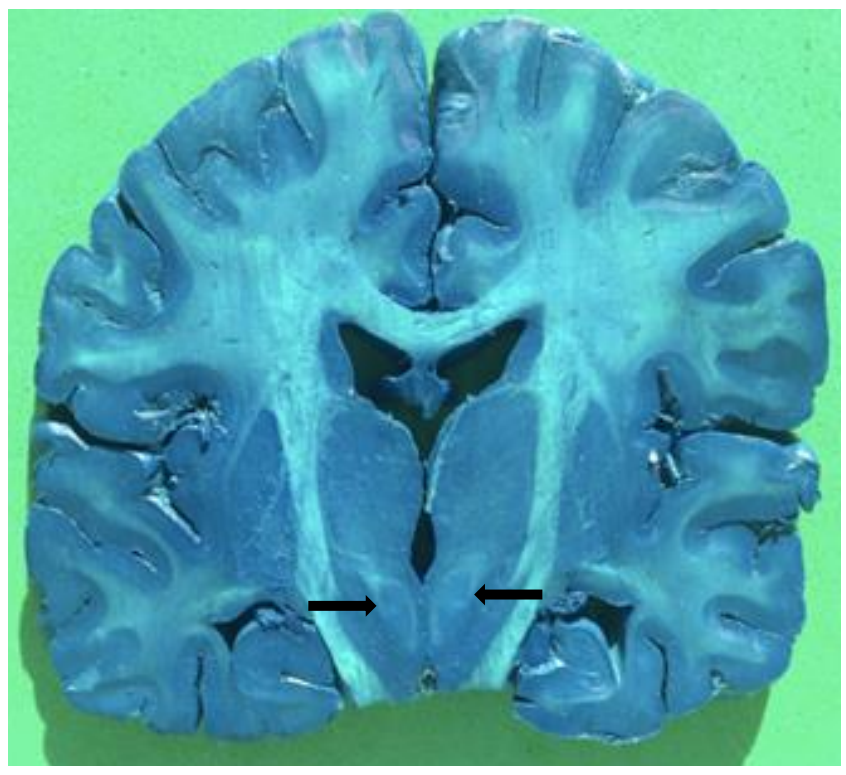

Source: Courtesy of Prof. PhD. Murilo Sousa de Meneses, Department of Anatomy, Universidade Federal do Paraná.

Figure 3. Gross anatomy. Photograph of fixed brain (coronal view) showing the subthalamic nucleus of Luys (arrows).

internal globus pallidus (GPi); ventrally, it is limited by the substantia nigra (SN) and cerebral peduncle; dorsally, by a portion of the fasciculus lenticularis and zona incerta, both of which separate it from the ventral thalamus; and medially, by the nucleus of the fields of Forel, the $\mathrm{H}$ field of Forel, and the posterior hypothalamic area (rostrally) and red nucleus (posteriorly and medially). The STN has three major functional roles: limbic (medial limbic territory), motor (large dorsolateral motor territory), and associative (ventromedial associative territory $)^{11,12}$.

\section{Subthalamic nucleus-related disorders}

Unilateral lesion of the STN leads to contralateral hemiballismus, a classical clinical observation that has also been experimentally demonstrated ${ }^{13,14,15,16}$. The etiology of such lesions varies and includes focal hemorrhagic and ischemic lesions; hyperglycemia and other metabolic disturbances; infections or parainfectious disorders; multiple sclerosis; primary or metastatic tumors; neonatal anoxic brain injury; and trauma ${ }^{14,15,16}$. Non-motor manifestations are more subtle and less frequent, but may include neuropsychiatric disorders such as hyperphagia, aggressiveness, anxiety, irritability, euphoria, and different types of impulse-control disor$\operatorname{ders}^{13,17}$. The crucial role of the STN in the pathophysiology of Parkinsonian signs and symptoms results from the fact that dopaminergic neuronal dysfunction induced by degeneration of the substantia nigra leads to STN hyperactivity secondary to dysfunctional dopamine $\mathrm{D} 2$ receptor signaling and inhibition of the external globus pallidus (GPe), the main STN inhibitor ${ }^{13,18,19}$. Although levodopa is the main and most effective medication for the treatment of motor symptoms in Parkinson's disease (PD), chronic treatment can be undermined by complications that include motor fluctuations and involuntary hyperkinetic movements (levodopa-induced dyskinesias). In these scenarios, neuromodulation techniques, including ablative surgery and deep brain stimulation of the STN (DBS-STN), can be effective ${ }^{18,19}$. DBS-STN has been used as an established therapy for selected patients with PD for over two decades ${ }^{18,19}$. However, the effects of DBS-STN are limited to certain motor aspects of PD, most notably appendicular rigidity, tremor, and bradykinesia. The procedure obviously involves acute and long-term complications, including perioperative complications, induction of other movement phenomena (e.g., capsular contractures, blepharospasm, and freezing of gait), and adverse effects on behavior and cognition ${ }^{18,19,20}$.

\section{Luys's last two decades of life and the shift in his academic interest}

In 1864, Luys was chosen to be the director of the Maison de Santé Esquirol, a mental health center in the small city of Ivry-sur-Seine, where he was mayor from 1869 to 1870. Luys suffered from progressive deafness in his later years, but remained academically active ${ }^{2,4,5,6}$. In 1886, he left the La Salpêtrière Hospital and started a new activity as head of the Charité Hospital, where he became more interested in hysteria and hypnotism ${ }^{2,5,6}$. From this period onward, his great academic prestige gradually dissipated, while he approached his final years emphatically devoting his attention to studies on more ethereal topics, particularly esotericism, generating fierce criticism from the academic community, while his innumerable contributions to neuroscience were relegated to the background ${ }^{2,4,5,6}$. He practiced hypnosis using approaches that were unique compared with his contemporaries (Charcot and others), such as associating test tubes with drugs and toxic substances presented to the patient during the session, and practicing hypnotism in public sessions, including laypeople ${ }^{6,21}$. Moreover, he studied the socalled brain emanations and the interface of magnetism and hypnosis. ${ }^{22,23}$ His last talk was at the Congress of Psychology, Munich, in 1896 on the "structure of the brain," just one year before his sudden death at the age of $69^{2,4,5,6}$. In December 1987, Ernest Cadet, secretary of the l'Académie de médecine at the time, wrote a posthumous tribute to Luys, emphasizing their 40-year friendship and Luys's honesty and investigative spirit $2,4,5,6$.

\section{CONCLUSION}

We have described Jules Bernard Luys's scientific career, from his early studies on neuroanatomy, culminating in the description of the STN, to the final years of his life, when he developed an interest in hysteria, hypnosis, and esotericism, leading him to unconventional experiments in these fields. 
1. Goetz CG, Bonduelle M, Gelfand T. Charcot: constructing neurology. New York: Oxford University Press, 1995. p. 217-67.

2. Parent M, Parent A. Jules Bernard Luys in Charcot's penumbra. Front Neurol Neurosci. 2011 Oct;29:125-136. https://doi. org/10.1159/000321782

3. Lanska DJ. Chapter 33: the history of movement disorders. Handb Clin Neurol. 2009 Nov;95:501-46. https://doi.org/10.1016/S00729752(08)02133-7

4. Pearce JM. The subthalamic nucleus and Jules Bernard Luys (1828-97). J Neurol Neurosurg Psychiatry. 2001 Dec;71(6):783. http:// dx.doi.org/10.1136/jnnp.71.6.783

5. Parent A. Jules Bernard Luys and the subthalamic nucleus. Mov Disord. 2002 Jan;17(1):181-5. https://doi.org/10.1002/mds.1251

6. Parent A, Parent M, Leroux-Hugon V. Jules Bernard Luys: a singular figure of 19th century neurology. Can J Neurol Sci. 2002 Aug;29(3):282-8. https://doi.org/10.1017/S0317167100002080

7. De Rijcke S. Light tries the expert eye: the introduction of photography in nineteenth-century macroscopic neuroanatomy. J Hist Neurosci. 2008;17(3):349-66. https://doi. org/10.1080/09647040701593788

8. Harrington A. Metals and magnets in medicine: hysteria, hypnosis and medical culture in fin-de-siècle Paris. Psychol Med. 1988 Feb;18(1):21-38. https://doi.org/10.1017/s0033291700001859

9. Clarac F, Barbara JG, Broussolle E, Poirier J. Figures and institutions of the neurological sciences in Paris from 1800 to 1950. Introduction and Part I: Neuroanatomy. Rev Neurol (Paris). 2012 Jan;168(1):2-14. https://doi.org/10.1016/j.neurol.2011.08.013

10. Hameleers R, Temel Y, Visser-Vandewalle V. History of the Corpus Luysii: 1865-1995. Arch Neurol. 2006 Sep;63(9):1340-2. https://doi. org/10.1001/archneur.63.9.1340

11. Benarroch EE. Subthalamic nucleus and its connections Anatomic substrate for the network effects of deep brain stimulation. Neurology. 2008 May;70(21):1991-5. https://doi.org/10.1212/01. wnl.0000313022.39329.65

12. Marani E, Heida T, Lakke EA, Usunoff KG. The subthalamic nucleus. Part I: development, cytology, topography and connections. Adv Anat Embryol Cell Biol. 2008;198:1-113, vii. PMID: 18727483
13. Hamani C, Saint-Cyr JA, Fraser J, Kaplitt M, Lozano AM. The subthalamic nucleus in the context of movement disorders. Brain. 2004 Jan;127(1):4-20. https://doi.org/10.1093/brain/awh029

14. Martin JP. Hemichorea resulting from a local lesion of the brain: the syndrome of the body of Luys. Brain. 1927 Oct;50(3-4):637-51. https://doi.org/10.1093/brain/50.3-4.637

15. Dewey RB Jr, Jankovic J. Hemiballism-hemichorea. Clinical and pharmacologic findings in 21 patients. Arch Neurol. 1989 Aug;46(8):862-7.https://doi.org/10.1001/archneur.1989.00520440044020

16. Coral P, Teive HAG, Werneck LC. Hemibalismo: relato de oito casos. Arq Neuropsiquiatr. 2000 Set;58(3-A):698-703. https://doi. org/10.1590/S0004-282X2000000400016

17. Choi BS, Shen G, Nan G, Kim JM, Jung KY, Jeon B. Dramatic psychiatric and behavioral symptoms following a subthalamic lesion. J Clin Neurosci. 2018 Jan;47:154-6. https://doi.org/10.1016/j.jocn.2017.10.051

18. Lang AE, Espay AJ. Disease modification in Parkinson's disease: current approaches, challenges, and future considerations. Mov Disord. 2018 May;33(5):660-77. https://doi.org/10.1002/mds.27360

19. Brandão P, Grippe TC, Modesto LC, Ferreira AGF, Da Silva FM, Pereira FF, et al. Decisions about deep brain stimulation therapy in Parkinson's disease. Arq Neuropsiquiatr. 2018 Jun;76(6):411-20. https://doi.org/10.1590/0004-282×20180048

20. Baizabal-Carvallo JF, Jankovic J. Movement disorders induced by deep brain stimulation. Parkinsonism Relat Disord. 2016 Apr;25:1-9. https://doi.org/10.1016/j.parkreldis.2016.01.014

21. Luys JB. Les émotions chez les sujets en état d'hypnotisme: études de psychologie expérimentale faites à l'aide de substances médicamenteuses ou toxiques. Paris: J.B. Baillière et Fils; 1887.

22. Luys JB. Revue d’Hypnologie théorique et pratique. Paris: George Carrés Éditeur; 1890. Action psychique des aimants. Des courants électromagnétiques et des courants électriques continus;74-83 and 107-12.

23. Luys JB. Annales de psychiatrie et d'hypnologie dans leurs rapports avec la psychologie et la médecine légale. Paris: Bureau des annales de psychiatrie et d'hypnologie; 1893. p. 65-67.

24. Luys JB. L'Encéphale: journal des maladies mentales et nerveuses [internet]. Paris: G. Masson éditeur; 1881.909 p. [Accessed on June 27, 2018]. Available from: https://gallica.bnf.fr/ark:/12148/bpt6k5600499z 